\title{
NO EVIDENCE FOR HISTORICAL DECLINES IN POLLINATION SUCCESS IN HUNGARIAN ORCHIDS
}

\author{
MOLNÁR V., A. ${ }^{1 *}$ - LÖKI, V. ${ }^{1}-$ TAKÁCS, A. $^{1}-$ SCHMIDT, J. ${ }^{2}-$ TÖKÖLYI, J. ${ }^{2}-$ \\ BÓDIS, J. ${ }^{3}-$ SRAMKÓ, G. ${ }^{1,3}$ \\ ${ }^{I}$ Department of Botany, University of Debrecen, \\ Egyetem tér 1., H-4032, Debrecen, Hungary, \\ (phone: +36-52-512-900/62648; fax: +36-52-512-943) \\ ${ }^{2}$ MTA-DE Lendület' Behavioural Ecology Research Group, Department of Evolutionary \\ Zoology, University of Debrecen, \\ Egyetem tér 1., H-4032 Debrecen, Hungary, \\ (phone: +36-52-512-900/62331; fax: +36-52-512-941) \\ ${ }^{3}$ Department of Plant Sciences and Biotechnology, University of Pannonia, \\ Georgikon Faculty, \\ H-8360 Keszthely, Festetics u. 7., Hungary, \\ (phone: +36-83-545-095; fax: +36-83-545-058); \\ ${ }^{4}$ MTA-ELTE-MTM Ecology Research Group, \\ Pázmány Péter sétány 1/C, H-1117 Budapest, Hungary \\ (phone: +36-52-512-900/62632; fax: +36-52-512-943) \\ *Corresponding author \\ e-mail: mva@science.unideb.hu \\ (Received $3^{\text {rd }}$ Feb 2015; accepted $11^{\text {th }}$ Mar 2015)
}

\begin{abstract}
Pollination crisis (the decline of pollinator populations) is a global phenomenon which threatens biodiversity, human welfare and economy. The degree to which different plant populations/species are affected by pollination crisis is still unclear. In this study, long-term herbarium dataset was used to quantify the reproduction rate of Hungarian orchids between 1853 and 2008. We quantified fruit-set rate of 663 specimens belonging to 27 species. Data were available from an average of $10.3 \pm 9.3$ localities, $76.5 \pm 43.2$ years, and $23.4 \pm 25.6$ specimens per species. Herbarium data were validated with field-observed data in case of the different pollination strategies. According to our results, the reproductive success of the vast majority of orchid species has not changed during time and pollination crisis is not apparent in Hungary at least until the end of the 20th century.
\end{abstract}

Keywords: herbaria, natural history collections, Orchidaceae, pollination crisis, pollination mode

\section{Introduction}

Pollinators provide key ecosystem services in most terrestrial ecosystems (Chee, 2004; Boyd and Banzhaf, 2007; Wallace, 2007; Fisher and Turner, 2008). Their activity is crucially important in the long-term survival of indigenous plant communities (Ashman et al., 2004; Aguilar et al., 2006) and the productivity of cultivated plants (Klein et al., 2007; Ricketts et al., 2008). For most crop plants and wild plants (particularly in the temperate climate zones) the most important pollinators are insects, especially bees, which are declining parallel to insect-pollinated plants at global (Kearns et al., 1998; Potts et al., 2010) and western European (Biesmeijer et al., 2006) scale.

The main causes of the observed global pollination crisis have not been fully identified, but are potentially connected to the fragmentation and destruction of (semi-) 
natural habitats, spread of parasites, the use of chemicals in agriculture and global climate change. From this point of view, the recent and well documented climate change (Parmesan and Yohe, 2003; Root et al., 2003; Schröter et al., 2005; IPCC, 2007) deserves particular attention. Phenological shifts linked to changing climatic conditions were documented in different groups of plants (Fitter and Fitter, 2002; Parmesan, 2006; Post et al., 2008), including orchids (Robbirt et al., 2011; Molnár V. et al., 2012b). So far, little is known about climatic responsiveness of orchid-pollinators, but pollination mode was found to be the most important predictor of phenological response of central European terrestrial orchids (Molnár V. et al. 2012b). Nevertheless, any phenological mismatch between pollinators and flowering plants may substantially reduce the reproductive success of plants through decreased pollination efficiency (Fitter and Fitter, 2002; Hegland et al., 2009; Bartomeus et al., 2011; Rafferty and Ives, 2011). European terrestrial orchids represent an ideal research object for studying temporal changes in pollination efficiency for several reasons. First, since agamospermy (asexual seed production) is very rare in the family (Nygren, 1967; Catling and Catling, 1991), the presence of a fruit is almost always an indication of successful pollination (Neiland and Wilcock, 1995). Second, individual reproductive success of orchids is easy to estimate by counting the flowers and fruits on the shoot (Neiland and Wilcock, 1998). Third, orchids exhibit diverse pollination modes (self-pollinating, nectar-rewarding, food- and sexual deception (Dafni, 1984; Jersáková et al., 2006), consequently, their dependence on the abundance and diversity of pollinating insects differs between species. Fourth, different orchid species are attractive for specific group of insects, such as bees and wasps (Hymenoptera), butterflies (Lepidoptera) and beetles (Coleoptera) (Claessens and Kleynen, 2011).

Our aims in this study were (1) to characterize Hungarian orchid species in terms of reproductive success based on herbarium records, (2) determine the effect of pollination mode on fertilization success and (3) evaluate historical changes in reproductive success in orchids during the past decades.

Our predictions were the following: the reproductive success of autogamous species is temporarly invariable and relatively high (since they do not depend on pollinators), the reproductive success of entomophilous species depends on pollination mode: nectarrewarding species show higher fructification rate than deceptive taxa, the reproductive success of entomophilous species (both nectar rewarding and deceptive) is decreasing due to the decline of pollinator populations.

Natural history collections contain important and useful information on the reproductive success of orchids in historical context (Farrell, 1985; Pauw and Hawkins, 2011). To test our hypotheses we collected data on fructification rate from all publicly accessible Hungarian herbaria and analyzed these with respect to pollination mode and time of collection.

\section{Materials and methods}

\section{Quantifying fruit-set}

We used the most widely utilised (and the easiest) method of measuring of reproductive success in orchids: quantifying fruit-set (Neiland and Wilcock, 1998). The Herbarium Database of Hungarian Orchids, compiled recently (Molnár V. et al., 2012a) allowed us to analyse reproductive success of 681 specimens belonging to 27 species based on a historical dataset which spans 155 years (Table 1). 
Table 1. List of the species and characterization of the dataset used in this study. Abbreviations: A - autogamous, FD-food deceptive, NR-nectar rewarding.

\begin{tabular}{|c|c|c|c|c|c|}
\hline \multirow[b]{2}{*}{ Species } & \multirow[b]{2}{*}{$\begin{array}{l}\text { Pollination } \\
\text { mode }\end{array}$} & \multirow[b]{2}{*}{$\begin{array}{c}\text { No. of } \\
\text { localities }\end{array}$} & \multicolumn{2}{|c|}{ Date of collection } & \multirow[b]{2}{*}{$\begin{array}{c}\text { No. of } \\
\text { specimens }\end{array}$} \\
\hline & & & $\operatorname{Median} \pm$ SD & $\begin{array}{c}\text { Duration } \\
\text { (years) }\end{array}$ & \\
\hline Anacamptis coriophora & NR & 11 & $1944 \pm 17$ & 55 & 33 \\
\hline Anacamptis morio & FD & 7 & $1945 \pm 26$ & 73 & 15 \\
\hline Anacamptis palustris & FD & 4 & $1944 \pm 52$ & 106 & 7 \\
\hline $\begin{array}{l}\text { Anacamptis } \\
\text { pyramidalis }\end{array}$ & FD & 14 & $1956 \pm 40$ & 134 & 27 \\
\hline $\begin{array}{l}\text { Cephalanthera } \\
\text { damasonium }\end{array}$ & A & 31 & $1946 \pm 32$ & 132 & 71 \\
\hline $\begin{array}{l}\text { Cephalanthera } \\
\text { longifolia }\end{array}$ & FD & 23 & $1939 \pm 26$ & 104 & 30 \\
\hline Cephalanthera rubra & FD & 9 & $1954.5 \pm 12$ & 29 & 16 \\
\hline Cypripedium calceolus & FD & 3 & $1939.5 \pm 13$ & 27 & 6 \\
\hline Dactylorhiza incarnata & FD & 19 & $1948 \pm 29$ & 126 & 24 \\
\hline Dactylorhiza viridis & NR & 7 & $1947 \pm 11$ & 25 & 17 \\
\hline Epipactis atrorubens & NR & 8 & $1919 \pm 21$ & 61 & 24 \\
\hline Epipactis helleborine & NR & 9 & $1926 \pm 19$ & 71 & 17 \\
\hline Epipactis microphylla & A & 22 & $1937 \pm 36$ & 149 & 71 \\
\hline Epipactis palustris & A & 16 & $1937 \pm 31$ & 112 & 48 \\
\hline Epipactis purpurata & NR & 11 & $1952 \pm 22$ & 77 & 24 \\
\hline Epipactis tallosii & A & 3 & $1948 \pm 38$ & 66 & 6 \\
\hline Goodyera repens & NR & 2 & $1954 \pm 1$ & 2 & 6 \\
\hline Gymnadenia conopsea & NR & 5 & $1922 \pm 39$ & 106 & 7 \\
\hline $\begin{array}{l}\text { Gymnadenia } \\
\text { odoratissima }\end{array}$ & NR & 2 & $1904 \pm 55$ & 95 & 8 \\
\hline Limodorum abortivum & A & 14 & $1952 \pm 30$ & 93 & 26 \\
\hline Liparis loeselii & A & 2 & $1969 \pm 16$ & 38 & 10 \\
\hline Neottia ovata & A & 12 & $1949.5 \pm 34$ & 134 & 16 \\
\hline $\begin{array}{l}\text { Neottia } \\
\quad \text { nidus-avis }\end{array}$ & A & 38 & $1950 \pm 29$ & 121 & 119 \\
\hline Orchis militaris & FD & 13 & $1951 \pm 31$ & 91 & 59 \\
\hline Orchis purpurea & FD & 5 & $1942 \pm 31$ & 77 & 6 \\
\hline Orchis simia & FD & 2 & $1961 \pm 42$ & 60 & 9 \\
\hline Platanthera bifolia & NR & 25 & $1946 \pm 32$ & 137 & 31 \\
\hline
\end{tabular}

We considered only intact herbarium specimens collected in fruiting stage (Fig. 1). The number of flowers (both fertilized and non-fertilized) and the number of fruits were counted on each specimen collected at fruiting stage and identified at species level.

For statistical analyzes we used only species for which at least 3 herbarium records were collected. In the whole dataset the mean $\pm \mathrm{SD}$ numbers of records / species were 23.4 \pm 25.6 , which were collected from 10.3 \pm 9.3 localities, during $76.5 \pm 43.2$ years.

\section{Life-history characterisation}

Species were categorized into three groups according to their pollination mode autogamy (including obligate and facultative self-pollination), nectar-rewarding entomophily and food deceptive entomophily, following Molnár V. et al. (2012b). A full list of all investigated species, as well as the sequence data used for phylogenetic reconstruction, is given in Table 1. 

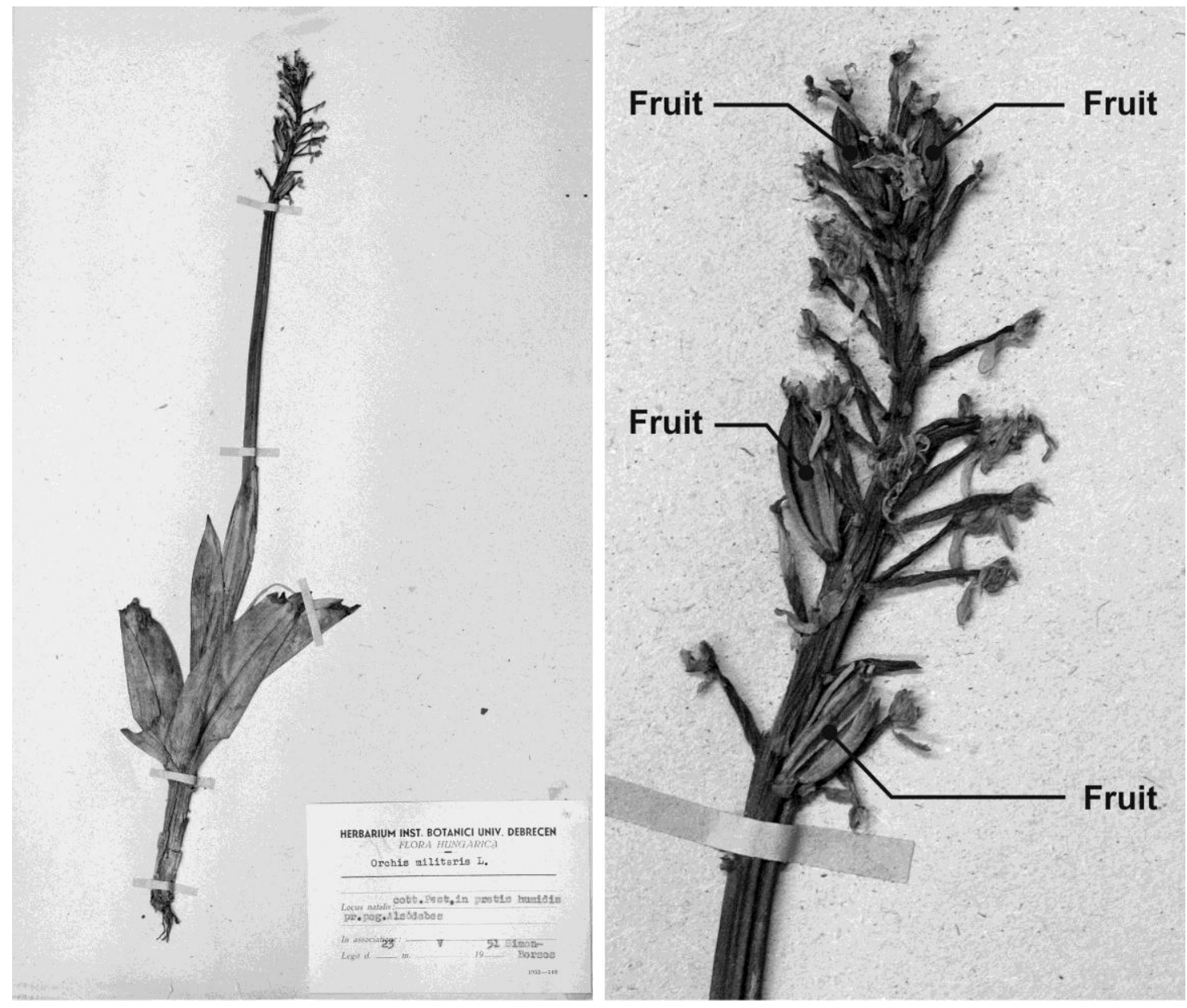

Figure 1. Orchis militaris sheet from the collection of the Department of Botany at the University of Debrecen (DE), collected near to Dabas on the 23th of May in 1951, by Tibor Simon and Olga Borsos. Its four fruits are well identifiable.

\section{Statistical analyses}

To analyze historical changes in reproductive success and its relationship to pollination mode, we used generalized linear mixed models (GLMMs). Since fruit-set is proportion data following a binomial distribution, we used binomial GLMMs with the number of fruits (successes) and number of unpollinated flowers (failures) as a bivariate response. Binomial GLMMs were performed using the MCMCglmm package (Hadfield, 2010) in the R Statistical Environment (R Core Team, 2014). MCMCglmm implements a Bayesian version of traditional GLMMs and it has the advantage that it can incorporate complex covariance structure in the random effects, such as the covariance arising from the phylogenetic relationship between species; hence, these models can be used to evaluate the relationship between species traits while controlling for the non-independence of data points arising from shared phylogenetic descent.

To prepare a phylogenetic tree that describes phylogenetic distances between the species studied, we used one of the most useful molecular phylogenetic marker, the nuclear ribosomal internal transcribed spacer (nrITS) region (Baldwin et al., 1995; Álvarez and Wendel, 2003). An alignment of the sequences was made by eye in BioEdit v.7.1.3 (Hall, 1999). The resulting matrix was subject to phylogenetic tree 
reconstruction under the maximum parsimony (MP) criterion in Paup v.4.0b*10 (Swofford, 2003) using a heuristic search with default settings but holding 10 trees at each iteration step and repeating the search 1000-times. As we used a geographically strongly biased sample-set (Hungarian orchids), we had to apply a backbone constraint to overcome false tree-reconstruction due to suboptimal taxon sampling. Thus, the well-established phylogenetic relationship of European orchids (Bateman et al., 2003; Bateman et al., 2005; Bateman, 2009) was fixed as constraint (see Fig. 2). The most parsimonious phylogenetic trees compatible with our constraint were saved with branch length corresponding to mutational changes (i.e. as phylograms), then one of these trees was made ultrametric by applying the non-parametric rate smoothing algorithm (Sanderson, 1997) as implemented in r8s v.1.71 (Sanderson, 2003). Statistical robustness of our MP reconstruction was assessed by the non-parametric bootstrap procedure applying 1000 pseudo-replicates in Paup. This above procedure allowed us to assess the genetic distance between each species we studied, and the resulting ultrametric tree (Fig. 2) was used as input for analyses using the phylogenetic control.

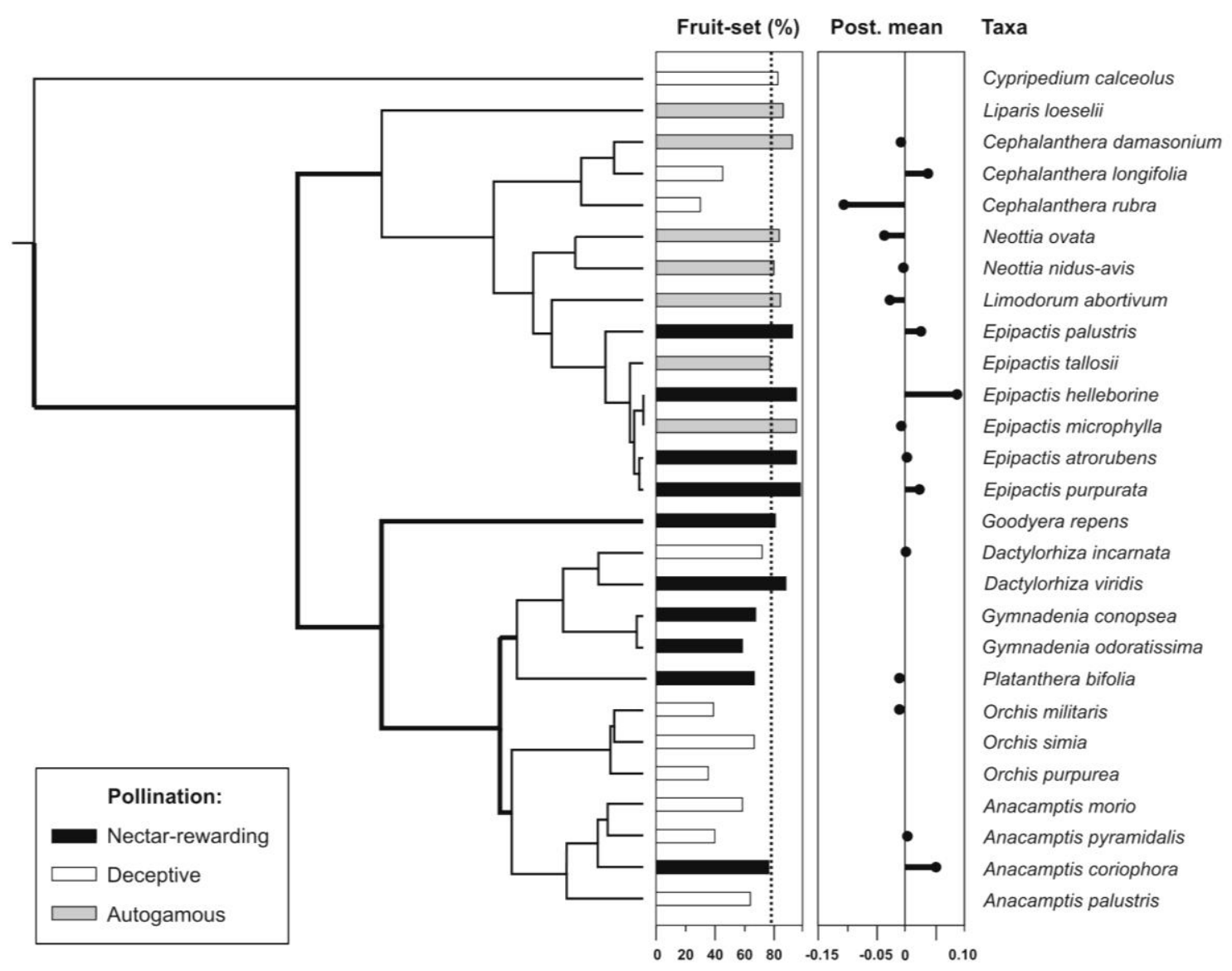

Figure 2. The favoured phylogenetic tree of four equally most parsimonious trees made ultrametric by non-parametric rate smoothing and used in analysis as phylogenetic control. The backbone constraint applied in the heuristic MP search is indicated by thick branches. Mean fruit-set values calculated (dashed line represents median) for each taxon and changes in fruitset rates (posterior mean from Bayesian GLMM, see Table 4) calculated for 16 species are given next to the tree. 
We first evaluated the effect of pollination mode on fruit-set; as random factors we included the ID of herbarium records (to control for multiple plant individuals collected at the same time from the same location), species (to control for multiple records per species) and phylogenetic position (to control for shared phylogenetic descent). Next we built a similar model with year as fixed effect, and a third model with the interaction of these two factors.

Lastly, we evaluated temporal changes in fruit-set in species where the number of records per species was $>10$ (this was the case for $\mathrm{N}=16$ species). These latter models were evidently run without phylogenetic control, but we included the ID of herbarium records as a random factor.

\section{Results}

The phylogenetic tree reconstruction found four equally parsimonious trees under the MP criterion that were compatible with the backbone constraint applied. These four trees at step 1320 were found repeatedly during the 1000 random repetitions. The difference between the trees effected the tips; on one part of the trees Limodorum abortivum was sister to the genus Neottia, while the other part was affected by the exchanged placement of Orchis militaris and O. purpurea. All these placements are poorly resolved in the currently available studies. The finally favoured tree (Fig. 2) is the one fully compatible with those published in the relevant literature (Bateman et al., 2003; Bateman et al., 2005; Bateman, 2009).

Species-specific fruit-set rates in the 27 species ranged between $35 \%$ and $98 \%$. (Table 2). Pollination mode had a significant effect on reproductive success; compared to nectar-rewarding species, deceptive taxa had significantly lower fruit-set (posterior mean: -2.152; lower: -3.380; upper 95\% CI: -1.079; p=0.004). Fruit-set of autogamous taxa was not significantly different from nectar-rewarding ones (posterior mean: 0.747; lower: -0.577; upper 95\% CI: -1.796; p=0.224) (Table 3, Fig. 3).

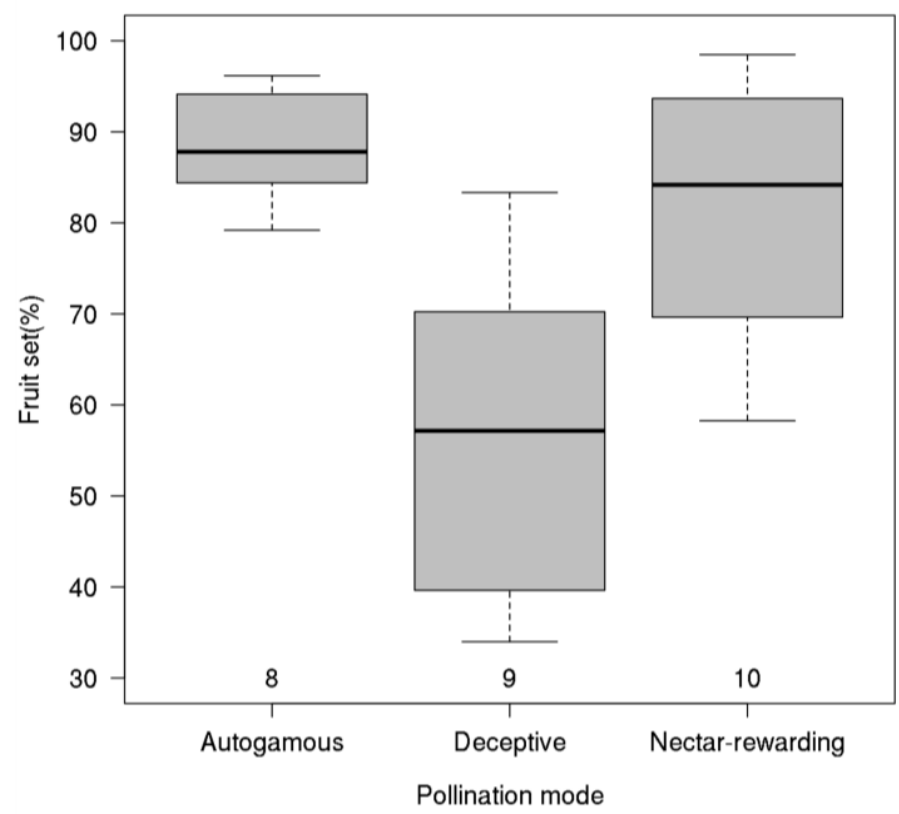

Figure 3. Reproductive success of orchids with different pollination mode. The number of species with each pollination strategy is indicated below the boxes. 
Table 2. Descriptive statistics on fruit-set data of species examined in this study.

\begin{tabular}{l|c|c|c|c|c}
\hline & \multicolumn{2}{|c|}{ Number of flowers } & \multicolumn{2}{|c|}{ Number of fruits } & Fruit-set (\%) \\
Species & Total & Mean & Total & Mean & Mean \pm SD \\
\hline Anacamptis coriophora & 512 & 15.5 & 394 & 11.9 & $77 \pm 17$ \\
Anacamptis morio & 147 & 9.8 & 86 & 5.7 & $59 \pm 15$ \\
Anacamptis palustris & 72 & 10.3 & 46 & 6.6 & $64 \pm 24$ \\
Anacamptis pyramidalis & 603 & 22.3 & 241 & 8.9 & $40 \pm 25$ \\
Cephalanthera damasonium & 344 & 4.9 & 321 & 4.5 & $93 \pm 13$ \\
Cephalanthera longifolia & 236 & 7.9 & 106 & 3.5 & $45 \pm 39$ \\
Cephalanthera rubra & 164 & 10.3 & 50 & 3.1 & $30 \pm 34$ \\
Cypripedium calceolus & 6 & 1.0 & 5 & 0.8 & $83 \pm 25$ \\
Dactylorhiza incarnata & 527 & 22.0 & 380 & 15.8 & $72 \pm 28$ \\
Dactylorhiza viridis & 217 & 12.8 & 190 & 11.2 & $88 \pm 11$ \\
Epipactis atrorubens & 362 & 15.1 & 347 & 14.5 & $96 \pm 4$ \\
Epipactis helleborine & 287 & 16.9 & 275 & 16.2 & $96 \pm 22$ \\
Epipactis microphylla & 799 & 11.3 & 769 & 10.8 & $96 \pm 4$ \\
Epipactis palustris & 522 & 10.9 & 486 & 10.1 & $93 \pm 8$ \\
Epipactis purpurata & 527 & 22.0 & 518 & 21.6 & $98 \pm 3$ \\
Epipactis tallosii & 85 & 14.2 & 66 & 11.0 & $78 \pm 27$ \\
Goodyera repens & 96 & 16.0 & 78 & 13.0 & $81 \pm 9$ \\
Gymnadenia conopsea & 145 & 20.7 & 99 & 14.1 & $68 \pm 31$ \\
Gymnadenia odoratissima & 175 & 21.9 & 104 & 13.0 & $59 \pm 19$ \\
Limodorum abortivum & 280 & 10.8 & 239 & 9.2 & $85 \pm 16$ \\
Liparis loeselii & 38 & 3.8 & 33 & 3.3 & $87 \pm 14$ \\
Neottia ovata & 556 & 34.8 & 467 & 29.2 & $84 \pm 13$ \\
Neottia nidus-avis & 2990 & 25.1 & 2386 & 20.1 & $80 \pm 7$ \\
Orchis militaris & 1243 & 21.1 & 483 & 8.19 & $39 \pm 18$ \\
Orchis purpurea & 193 & 32.2 & 67 & 11.2 & $35 \pm 14$ \\
Orchis simia & 146 & 16.2 & 98 & 10.9 & $67 \pm 24$ \\
Platanthera bifolia & 494 & 15.9 & 330 & 10.7 & $67 \pm 24$ \\
\hline
\end{tabular}

Table 3. Mean fruit-set rates of the species with different reproductive strategy

\begin{tabular}{c|c|ccc|ccc}
\hline & Number & \multicolumn{3}{|c|}{ Number of flowers } & \multicolumn{3}{c}{ Number of fruits } \\
& of species & Median & Mean & SD & Median & Mean & SD \\
\hline Autogamous & 9 & 10.9 & 13.5 & 10.2 & 10.1 & 11.5 & 8.3 \\
Food deceptive & 12 & 13 & 14.9 & 8.4 & 6.3 & 6.9 & 4.4 \\
Nectar rewarding & 10 & 16.4 & 17.7 & 3.3 & 13.6 & 14.4 & 3.4 \\
\hline
\end{tabular}

Fruit-set did not change with time (posterior mean: -0.004 ; lower: -0.011 ; upper $95 \%$ CI: 0.002; p=0.194, Fig. 4.). Furthermore, when year and pollination mode were included in interaction with each other (allowing different temporal changes in the three pollination strategies), none of the model parameters were significant.

Fruit-set decreased significantly with time in Neottia ovata, increased with time in Anacamptis coriophora, and no statistically significant trend was seen in the remainder of species with at least 10 herbarium records (14 out of 16; Table 4). 

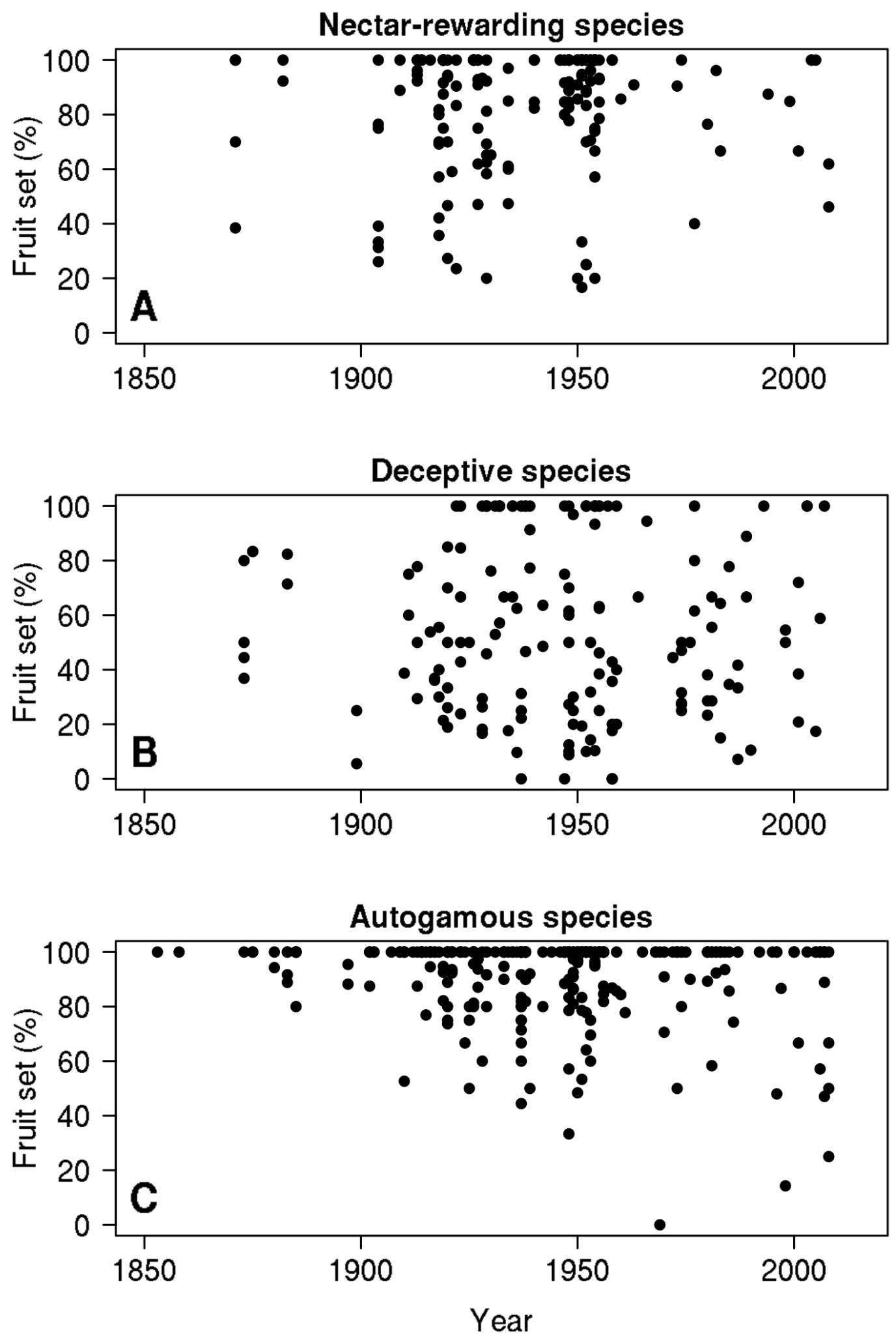

Figure 4. Fruit-set data of nectar-rewarding (A), deceptive (B) and autogamous $(C)$ taxa in relation to year of collection. Overall, there was no significant temporal changes in fructification rate (see Results) 
Table 4. Changes in fruit-set rate during time (results from Bayesian Generalized Linear Mixed Models). Boldface indicates statistically significant change.

\begin{tabular}{lcccc}
\hline Species & $\begin{array}{c}\text { Parameter estimate (posterior } \\
\text { mean) }\end{array}$ & $\begin{array}{c}\text { Lower 95\% } \\
\text { CI }\end{array}$ & $\begin{array}{c}\text { Upper 95\% } \\
\text { CI }\end{array}$ & pMCMC \\
\hline Anacamptis coriophora & $\mathbf{0 . 0 5 2}$ & $\mathbf{0 . 0 0 9}$ & $\mathbf{0 . 0 9 4}$ & $\mathbf{0 . 0 2 0}$ \\
Anacamptis pyramidalis & 0.004 & -0.016 & 0.023 & 0.750 \\
Cephalanthera damasonium & -0.007 & -0.035 & 0.024 & 0.622 \\
Cephalanthera longifolia & 0.039 & -0.077 & 0.141 & 0.422 \\
Cephalanthera rubra & -0.104 & -0.277 & 0.025 & 0.104 \\
Dactylorhiza incarnata & 0.003 & -0.032 & 0.047 & 0.896 \\
Epipactis atrorubens & 0.003 & -0.054 & 0.061 & 0.996 \\
Epipactis helleborine & 0.088 & -0.376 & 0.875 & 0.734 \\
Epipactis microphylla & -0.006 & -0.037 & 0.019 & 0.700 \\
Epipactis palustris & 0.027 & -0.035 & 0.095 & 0.360 \\
Epipactis purpurata & 0.024 & -0.084 & 0.158 & 0.694 \\
Limodorum abortivum & -0.026 & -0.070 & 0.025 & 0.214 \\
Neottia ovata & $\mathbf{- . 0 3 5}$ & $\mathbf{- 0 . 0 7 2}$ & $\mathbf{0 . 0 0 1}$ & $\mathbf{0 . 0 4 0}$ \\
Neottia nidus-avis & -0.003 & -0.021 & 0.012 & 0.666 \\
Orchis militaris & -0.010 & -0.026 & 0.010 & 0.266 \\
Platanthera bifolia & -0.010 & -0.035 & 0.014 & 0.398 \\
\hline
\end{tabular}

\section{Discussion}

Long-term data from herbaria were used to quantify the reproductive success of orchids in Hungary. Fruit-set rates of species with different pollination strategies are different; orchids with food deceptive strategy develop significantly less seedpods than autogamous species. This information is in accordance with field experiences (Neiland and Wilcock, 1998).

Our analyses seem to suggest that reproductive success in the vast majority (91\%) of Hungarian orchids has not changed temporally, i.e. pollination crisis has not occured in Hungary, at least until the end of the 20th century. Our results are in accordance with a recent paper of E. Vojtkó et al. (2015) who also reported relatively high recent reproduction success of two deceit pollinated Dactylorhiza species in comparison to Western European data.

In our dataset only two species showed significant temporal changes in their reproduction success: the Common Twayblade (Neottia ovata) showed a significant decrease in fruit set, while in the Bug Orchid (Anacamptis coriophora) reproduction success increased significantly. Because our study may have been adversely affected by varying temporal sampling frequency, the significant changes may be results of sampling bias.

There are at least two possible explanations to the detected trends. Firstly, the diversity of the bee communities is much higher in Hungary (Sárospataki et al., 2009), than in some Western European countries (Dauber et al., 2003; Hirsch and Wolters, 2003). Secondly, the very high and continuously increasing honeybee density in Hungary (Tóth, 2013) may contribute to the high recent reproductive success of deceit pollinated orchids (Biró et al., 2015) and also to the temporal invariability of reproduction success of orchids in Hungary. The only species (Anacamptis coriophora) with increasing fruit-set is 
pollinated by many different insects (Hymenoptera, Diptera, Hemiptera, Claessens and Kleynen, 2011) and also honeybee (Dafni and Ivri, 1979; Berger, 2004).

To summarize, our data show that compared to Western European populations, pollination crisis has not affected Hungarian orchids (at least in terms of reproductive success). This conclusion suggests that geographical variation needs to be taken account when studying the consequences of pollination crisis.

Acknowledgements. This research was supported by the European Union and the State of Hungary, cofinanced by the European Social Fund in the framework of TÁMOP-4.2.4.A/2-11/1-2012-0001 'National Excellence Program'. The instrumental and infrastructural support of OTKA K108992 Grant is also highly appreciated.

\section{REFERENCES}

[1] Aguilar, R., Ashworth, L., Galetto, L., Aizen, M.A. (2006): Plant reproductive susceptibility to habitat fragmentation: review and synthesis through a meta-analysis. Ecology Letters 9: 968-980.

[2] Ashman, T.L., Knight, T.M., Steets, J.A., Amarasekare, P., Burd, M., Campbell, D.R., Dudash, M.R., Johnston, M.O., Mazer, S.J., Mitchell, R.J., Morgan M.T., Wilson, W.G. (2004): Pollen limitation of plant reproduction: ecological and evolutionary causes and consequences. - Ecology 85: 2408-2421.

[3] Álvarez, I., Wendel, J.F. (2003): Ribosomal ITS sequences and plant phylogenetic inference. - Molecular Phylogenetics and Evolution 29: 417-434.

[4] Baldwin, B.G., Sanderson, M.J., Porter, J.M., Wojciechowski, M.F., Campbell, C.S., Donoghue, M. J. (1995): The ITS region of nuclear ribosomal DNA: a valuable source of evidence on angiosperm phylogeny. - Annals of the Missouri Botanical Garden 82: 247277.

[5] Bartomeus, I., Ascher, J.A., Wagner, D., Danfortd, B.N., Colla, S., Kornbluth, S., Winfree, R. (2011): Climate-associated phenological advances in bee pollinators and beepollinated plants. - Proceedings of the National Academy of Sciences USA 108: 2064520649.

[6] Bateman, R.M., Hollingsworth, P.M., Preston, J., Yi-Bo, L., Pridgeon, A.M., Chase, M.W. (2003): Molecular phylogenetics and evolution of Orchidinae and selected Habenariinae (Orchidaceae). - Botanical Journal ot the Linnaean Society 142: 1-40.

[7] Bateman, R.M., Hollingsworth, P.M., Squirrell, J., Hollingsworth, M.L. (2005): Tribe Neottieae. Phylogenetics. In: Pridgeon, A.M., Cribb, P.J., Chase, M.W., Rasmussen, F.N. (eds.): Genera Orchidacearum. Volume 4. Epidendroideae (Part One). - Oxford University Press, Oxford. pp: 487-495.

[8] Bateman, R.M. (2009): Evolutionary classification of European orchids: the crucial importance of maximising explicit evidence and minimising authoritarian speculation. Journal Europäischer Orchideen 41: 243-318.

[9] Berger, L. (2004): Observations sur le comportement da quelques pollinisateurs d'orchidées (3e partie). - L'Orchidophile 160: 19-35.

[10] Biesmeijer, J.C., Roberts, S.P.M., Reemer, M., Ohlemüller, R., Edwards, M., Peeters, T., Schaffers, A.P., Potts, S.G., Kleukers, R., Thomas, C.D., Settele, J., Kunin, W.E. (2006): Parallel declines in pollinators and insect-pollinated plants in Britain and the Netherlands. - Science 313: 351-354.

[11] Biró, É., Bódis, J., Nagy, T., Tökölyi, J., Molnár V., A. (2015): Honeybee (Apis mellifera) mediated increased reproductive success of a rare deceptive orchid. - Applied Ecology and Environmental Research 13: 181-192. 
[12] Boyd, J., Banzhaf, S. (2007): What are ecosystem services? - Ecological Economics 63: 616-626.

[13] Catling, P.M., Catling, V.R. (1991): A synopsis of breeding systems and pollination in North American orchids. - Lindleyana 6: 187-210.

[14] Chee, Y.E. (2004): An ecological perspective on the valuation of ecosystem services. Biological Conservation 120: 549-565.

[15] Claessens, J., Kleynen, J. (2011): The flower of the European orchid. Form and function. - Claessens \& Kleynen, Geuelle. 440 pp.

[16] Dafni, A. (1984): Mimicry and deception in pollination. - Annual Review of Ecology, Evolution, and Systematics 15: 259-278.

[17] Dafni, A., Ivri, Y. (1979): Pollination ecology and hybridization between Orchis coriophora L. and Orchis collina Sol. ex Russ. (Orchidaceae) in Israel. - New Phytologist 83(1): 181-187.

[18] Dauber, J., Hirsch, M., Simmering, D., Waldhardt, R., Otte, A., Wolters, V. (2003): Landscape structure as an indicator of biodiversity: matrix effects on species richness. Agriculture, Ecosystems \& Environment 98(1): 321-329.

[19] E. Vojtkó, A., Sonkoly, J., Lukács, B. A., Molnár V., A. (2015): Factors affecting reproductive success in three entomophilous orchid species in Hungary. - Acta Biologica Hungarica (accepted for publication)

[20] Farrell, L. (1985): Orchis militaris L. Biological flora of the British Isles No. 160. Journal of Ecology 73: 141-153.

[21] Fisher, B., Turner, R.K. (2008): Ecosystem services: Classification for valuation. Biological Conservation 141: 1167-1169.

[22] Fitter, A.H., Fitter, R.S.R. (2002): Rapid changes in flowering time in British plants. Science 296: 1689-1691.

[23] Hadfield, J.D. (2010): MCMC Methods for Multi-Response Generalized Linear Mixed Models: The MCMCglmm R Package. - Journal of Statistical Software 33(2): 1-22.

[24] Hall, T.A. (1999): BioEdit: a user-friendly biological sequence alignment editor and analysis program for Windows 95/98/NT. - Nucleic Acids Symposium Series 41: 95-98.

[25] Hegland, S.J., Nielsen, A., Lázaro, A., Bjerknes, A.L., Totland, Ø. (2009): How does climate warming affect plant-pollinator interactions? - Ecology Letters 12: 184-195.

[26] Hirsch, M., Wolters, V. (2003): Response of aculeate Hymenoptera to spatial features of an agricultural landscape. - Journal for Nature Conservation 11: 179-185.

[27] IPCC (2007): Intergovernmental Panel on Climate Change: Climate Change 2007: Impacts, Adaptation and Vulnerability. Contribution of Working Group II to the Fourth Assessment Report of the Intergovernmental Panel on Climate Change. - Cambridge University Press, Cambridge, UK.

[28] Jersáková, J., Johnson, S.D., Kindlmann, P. (2006): Mechanisms and evolution of deceptive pollination in orchids. - Biological Reviews 81: 219-235.

[29] Kearns, C.A., Inouye, D.W., Waser, N.M. (1998): Endangered mutualisms: the conservation of plant-pollinator interactions. - Annual Review of Ecology and Systematics 29: 83-112.

[30] Klein, A.M., Vaissiere, B.E., Cane, J.H., Steffan-Dewenter, I., Cunningham, S.A., Kremen, C., Tscharntke, T. (2007): Importance of pollinators in changing landscapes for world crops. - Proceedings of the Royal Society B: Biological Sciences 274: 303-313.

[31] Molnár V., A., Takács, A., Horváth, O., E. Vojtkó, A., Király, G., Sonkoly, J., Sramkó, G. (2012a): Herbarium Database of Hungarian Orchids I. Methodology, dataset, historical aspects and taxa. - Biologia 67: 79-86.

[32] Molnár V., A., Tökölyi, J., Végvári, Zs., Sramkó, G., Sulyok, J., Barta, Z. (2012b): Pollination mode predicts phenological response to climate change in terrestrial orchids: a case study from central Europe. - Journal of Ecology 100: 1141-1152. 
[33] Neiland, M.R.M., Wilcock, C.C. (1995): Maximization of reproductive success by European Orchidaceae under conditions of infrequent pollination. - Protoplasma 187: 3948.

[34] Neiland, M.R.M., Wilcock, C.C. (1998): Fruit set, nectar reward, and rarity in the Orchidaceae. - American Journal of Botany 85: 1657-1671.

[35] Nygren, A. (1967): Apomixis in the angiosperms. In: W. Ruhland (ed): Encyclopedia of plant physiology, Vol. XVIII. Sexuality, reproduction, alternation of generations. Springer, Berlin. pp. 551-596.

[36] Parmesan, C. (2006): Ecological and evolutionary responses to recent climate change. Annual Review of Ecology, Evolution, and Systematics 37: 637-669.

[37] Parmesan, C., Yohe, G. (2003): A globally coherent fingerprint of climate change impacts across natural systems. - Nature 421:37-42.

[38] Pauw, A., Hawkins, J.A. (2011): Reconstruction of historical pollination rates reveals linked declines of pollinators and plants. - Oikos 120: 344-349.

[39] Post, E.S., Pedersen, C., Wilmers, C.C., Forchhammer, M.C. (2008): Phenological sequences reveal aggregate life-history response to climatic warming. - Ecology 89: 363370.

[40] Potts, S.G., Biesmeijer, J.C., Kremen, C., Neumann, P., Schweiger, O., Kunin, W.E. (2010): Global pollinator declines: trends, impacts and drivers. - Trends in Ecology and Evolution 25: 345-353.

[41] R Core Team (2014): R: A language and environment for statistical computing. R Foundation for Statistical Computing, Vienna, Austria. URL http://www.R-project.org/.

[42] Rafferty, N.E., Ives, A.R. (2011): Effects of experimental shifts in flowering phenology on plant-pollinator interactions. - Ecology Letters 14: 69-74.

[43] Ricketts, T.H., Regetz, J., Steffan-Dewenter, I., Cunningham, S.A., Kremen, C., Bogdanski, A., Gemmill-Herren, B., Greenleaf, S.S., Klein, A.M., Mayfield, M.M., Morandin, L.A., Ochieng, A., Viana, B.F. (2008): Landscape effects on crop pollination services: are there general patterns? - Ecology Letters 11: 499-515.

[44] Robbirt, K.M., Davy, A.J., Hutchings, M.J., Roberts, D.L. (2011): Validation of biological collections as a source of phenological data for use in climate change studies: a case study with the orchid Ophrys sphegodes. - Journal of Ecology 99: 235-241.

[45] Root, T. L., Price, J.T., Hall, K.R., Schneider, S.H., Rosenzweig, C., Pounds, J.A. (2003): Fingerprints of global warming on wild animals and plants. - Nature 421: 57-60.

[46] Sanderson, M. J. (1997): A nonparametric approach to estimating divergence times in the absence of rate constancy. - Molecular Biololgy and Evolution 14: 1218-1231.

[47] Sanderson, M.J. (2003): r8s: inferring absolute rates of molecular evolution and divergence times in the absence of a molecular clock. - Bioinformatic 19: 301-302.

[48] Sárospataki, M., Báldi, A., Batáry, P., Józan, Z., Erdős, S., Rédei, T. (2009): Factors affecting the structure of bee assemblages in extensively and intensively grazed grasslands in Hungary. - Community Ecology 10: 182-188.

[49] Schröter, D., Cramer, W., Leemans, R., Prentice, I.C., Araújo, M.B., Arnell, N.W., Bondeau, A., Bugmann, H., Carter, T. R., Gracia, C. A., de la Vega-Leinert, A.C., Erhard, M., Ewert, F., Glendining, M., House, J.I., Kankaanpää, S., Klein, R.J.T., Lavorel, S., Lindner, M., Metzger, M.J., Meyer, J., Mitchell, T.D., Reginster, I., Rounsevell, M., Sabaté, S., Sitch, S., Smith, B., Smith, J., Smith, P., Sykes, M.T., Thonicke, K., Thuiller, W., Tuck, G., Zaehle, S., Zierl, B. (2005): Ecosystem service supply and vulnerability to global change in Europe. - Science 310: 1333-1337.

[50] Swofford, DL. (2003): PAUP*. Phylogenetic Analysis Using Parsimony (*and Other Methods). Version 4. - Sinauer Associates, Sunderland, Massachusetts.

[51] Tóth, P. (2013): Magyar Méhészeti Nemzeti Program Környezetterhelési Monitoring vizsgálat 2012-2013. - Országos Magyar Méhészeti Egyesület.

[52] Wallace, K.J. (2007): Classification of ecosystem services: problems and solutions. Biological Conservation 139: 235-246. 